\title{
Review of The Politics of Scale: A History of Range Science by Nathan Sayre
}

\author{
Matthew D. Turner
}

\author{
Book details \\ Sayre, NF \\ The Politics of Scale: A History of Range Science \\ Chicago: University of Chicago Press; 2017 \\ 288 pages, ISBN: Paper 978-022-608-X
}

Keywords: Nonequilibrium ecology, History of science, Ecological assessment, Range management

This is a book, as the title suggests, primarily concerned with the history of range science and particularly the development of range science in the USA. That said, it has much to offer Pastoralism readers as it provides fresh insights into a number of the different concepts that underlie rangeland management and assessment globally that continue to directly affect pastoral livelihoods. The book can be characterized as a social scientific analysis of range science - arguing, in general, that scientific knowledge and management institutions are co-produced within a broader politicaleconomic context. The book differs from this genre by its more sophisticated engagement with the scientific understandings and logics that underlie the development of range management. In this way, the book gives agency to individual scientists and sympathetically treats those who engaged with the complexity of rangeland systems. At the same time, it critically engages with range management science as it developed in the USA and was translated into international contexts. Sayre does this by taking political economy and institutional politics seriously. In this way, the equilibrium range science paradigm, while working as a management framework in some areas of the USA, persisted where it did not (in drier areas), despite the accumulation of the scientific evidence against it, because the paradigm provided the metrics necessary for management institutions and capital investment.

Sayre, one of the foremost theorists of 'scale' in the discipline of geography today, invokes the phrase 'politics of

Correspondence: mturner2@wisc.edu

Department of Geography, University of Wisconsin, 160 Science Hall, 550 N. Park Street, Madison, WI 53706, USA

(c) The Author(s). 2017 Open Access This article is distributed under the terms of the Creative Commons Attribution 4.0 International License (http://creativecommons.org/licenses/by/4.0/), which permits unrestricted use, distribution, and reproduction in any medium, provided you give appropriate credit to the original author(s) and the source, provide a link to the Creative Commons license, and indicate if changes were made. scale' in the book's title. This politics not only concerns contested shifts in governance scales in natural resource management but the less visible knowledge politics that surrounds range assessment. These are, in fact, rightly intertwined in Sayre's account. As should be familiar to many Pastoralism readers, a major feature of knowledge politics is a politics of confusion where scientific research poorly matches the management and livelihood realities of the object of concern (in this case 'rangelands'). The scale of most empirical range research was focused on the scale of the plot or range site while management requirements were needed at watershed or landscape scales. Not only do relevant ecological processes change with scale, but this scalar mismatch allowed a range management framework to persist despite the accumulation of contrary empirical findings (at different scales). This illustrates how the broad spatial extent of 'rangeland' has created on-going confusion and gaps between scientific work and management approaches. Sayre's attention to scale, both in terms of scientific practice and environmental governance, provides a useful analytical template for those working on issues of pastoralism where questions of scale abound.

Sayre explores these topics in a highly engaging and accessible style. In the introduction, he starts by discussing the dearth of range science histories and the complexity of the terms 'range' and 'rangeland' which are as much sociopolitical as ecological or land-cover categories. Rangelands are in essence a marginal category of expansive areas of limited productive potential - areas that are not cultivated, forested, or built upon. As such, they are 'sites where the separate and combined efforts of capital, science, and the

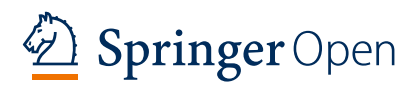


state meet their limits' (p. 2). This explains the lack of range science histories - these histories must necessarily chronicle that the object often changes and interventions often fail. The subsequent chapters are organized around a succession of themes about range interventions, ordered in rough chronological order.

Chapter 1 presents a fascinating exploration of the US government's pest eradication and fencing programmes during the early 1900s (the Progressive Era). Pests were considered as either animals that were seen as reducing the quality of forage for domestic livestock (prairie dogs, jack rabbits, etc.) or livestock predators (coyotes, wolves). Eradication efforts had long-term ecological effects with some foci of eradication now seen as keystone species. Fencing was seen as a means to protect livestock from predators without the labour costs of herders. The book describes the Coyote-Proof Pasture Experiment conducted in eastern Oregon between 1907 and 1909. Sayre describes this experiment as a key event in the eventual fencing of public rangelands in the USA. Given the interests in reducing labour costs, regularizing and measuring grazing charge, this experiment eventually led to the widespread use of less expensive fencing that was far from predator-proof on the rangelands of US public land. Overlapping grazing orbits managed by herders did not fit within the management vision of the Forest Service. In this way, bureaucratic and economic prerogatives, more than scientific evidence, led to the decline of herding in the USA.

Chapter 2 provides a much richer and nuanced account of the role of Clementsian ecology in the development of range science than is typically presented in the literature, showing how institutional prerogatives (fire suppression) and the needs of management in the service of capital led to the model of rangeland succession commonly critiqued in the literature today. The approach developed by the U.S. Forest Service between 1910-1930 was a somewhat perverted version of Clements's work and that of his student Arthur Sampson as shaped by the agency's institutional imperative against fire (with grazing as a tool for fire suppression) and the needs of both regulators and capital for fixed stocking rates regardless of changing rainfall conditions. This chapter will be of high concern for readers interested in range ecology and its equilibrium assumptions, because it provides a deeper account of how scientific models combined with institutional prerogatives produced a management model that has greatly influenced range assessment and management around the world. Moreover, the fire suppression part of the story will prove interesting for those readers who work with pastoralists in savanna/woodland environments where grazing interacts strongly with fire incidence and tree/bush cover.

Building from his own experience at the Jornada Experimental Range in New Mexico, Sayre, in chapter 3, provides accounts of early work at two important experimental stations in dryland USA: Jornada and the Santa Rita Experimental Range in Arizona. His reading of the reports coming out of these stations shows how early range scientists did not initially adopt the range succession model being promoted by the Forest Service. Instead, their work emphasized the role of rainfall variability rather than stocking rates as affecting species composition and productivity of rangelands (more consistent with nonequilibrium models). This account further shows the strength of the institutional imperatives supporting the range succession model with scientists at these stations finally adopting it in the 1930s in an attempt to explain problems of brush encroachment (with limited success).

Chapter 4 returns to the institutional politics that were behind the growth and maturation of the range succession model that looked to establish fixed stocking rates on rangeland types based on average climate conditions. The aim of applying the model was to manage rangeland systems in their desired states (based on species composition and standing biomass). Despite their limited relevance as a management tool for drier rangelands, there was much in favour of applying fixed stocking rates. Fixed metrics were useful for regulators, and such metrics became increasingly important as the Forest Service's vision of setting permissible stocking levels for grazing districts became generalized with the passage of the Taylor Grazing Act of 1934. Stocking rates were also useful tools for ranchers as economic metrics to shape their investments. The chapter traces how range assessment developed to produce necessary carrying capacities of rangelands to meet the needs of state agencies and ranchers alike. In so doing, this chapter carefully traces the logical lapses and unsupported assumptions that facilitated the scalar shifts from empirical data collection, rangeland assessment, and rangeland regulation. This is the chapter that most directly explores the mixing of social and ecological scales in range science.

Chapter 5 provides the flip side of range management based on equilibrium notions of ecology - inexplicable shifts in rangeland structure and the impossibility of relying on stocking rate alone to cause shifts in rangeland state. This follows the experience of rangelands in the southwestern USA where decades of equilibriumbased management and fire suppression led to transitions to new states - states that were undesirable from a management point of view but seemingly persistent despite subsequent variations in climate and stocking rates. The chapter traces the history of active manipulation (attempted restoration) of rangelands through combinations of reseedings and brush eradication. It is a fairly straightforward history of the failure of these approaches to have a widespread effect (given the large areas of rangeland). The chapter provides good examples of the 
thresholds and path dependency of rangeland ecology that were ignored earlier on but are now widely accepted (e.g. state-transition models of change).

The last two chapters present the internationalization of the US range science approach (chapter 6) and the eventual backlash against it (chapter 7). Given their expanded breadth and the author's areas of expertise (largely in the USA), these chapters are less rich in terms of range science practice, methodological interrogation, and institutional politics. But these chapters do provide interesting material that even those of us who are steeped in the international literature on equilibrium and nonequilibrium range ecology can learn from. In particular, Sayre's recounting of how American range scientists promoted their craft internationally (the case of the Inter-American conference in 1948 is interesting). Moreover, Sayre's treatment of the easy confluence of neo-Malthusian thought with range science around the concept of carrying capacity is also interesting. The discussion of the revisionist critique of equilibrium-based range science is a good summary of the confluence of social scientific critiques of range science as it was used in pastoral development (focusing on the arguments of Jeremy Swift in West Africa and Stephen Sandford (1983) in East Africa) with the rangeland ecologists (many being Australian) and modellers who were the first to relax equilibrium assumptions in rangeland contexts (e.g. Imanuel Noy-Mier (1975), Mark Westoby (1979), Jim Ellis (1998), Brian Walker (1981), and David Swift (1977)). This Anglophone-centric treatment follows the intersecting personal histories of some of the important players in the literature and international forums. Sayre describes how these efforts coalesced at the Woburn Conference in 1990 resulting in the publication of Behnke et al.'s (1993) volume entitled Range Ecology at Disequilibrium in 1993.

This is an important book. It is an accessible, engaging, and much-needed history of range science, particularly as it developed in the USA. This is not an encyclopedic history. It is a history that addresses big conceptual questions (many of which still remain) and that is attentive to the institutional and political-economic environments that shaped range science as it developed. Given the important influence of American range science on range assessment and management around the world, this is a history of real importance to those working with pastoral peoples. Sayre's meticulous and laser-sharp excavations of key concepts in range and environmental science (e.g. carrying capacity) are first rate. Moreover, the book is a model for interdisciplinary scholarship by not privileging one facet of the complex reality of range science experience but places the object of inquiry (rangelands), scientific inquiry, institutional politics, and the interests of capital at equal footing in the analysis. In so doing, it gives agency to the players in the story and thus conveys, at least to this reader, a sense of optimism. Opportunities for growth and change are revealed despite our troubled history of engagement with rangelands around the world.

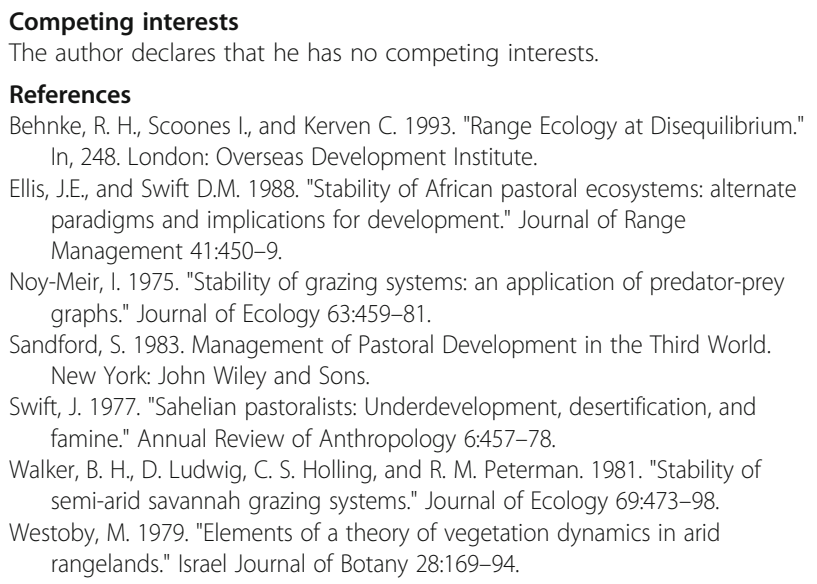

\section{Submit your manuscript to a SpringerOpen ${ }^{\odot}$ journal and benefit from:}

- Convenient online submission

- Rigorous peer review

- Open access: articles freely available online

- High visibility within the field

- Retaining the copyright to your article

Submit your next manuscript at $>$ springeropen.com 